\title{
Quantitative and qualitative analysis of sterols/sterolins and hypoxoside contents of three Hypoxis (African potato) spp.
}

\author{
Gerhardt J. Boukes, Maryna van de Venter* and Vaughan Oosthuizen \\ Department of Biochemistry and Microbiology, Faculty of Science, PO Box 77000, Nelson Mandela Metropolitan \\ University, Port Elizabeth 6031, South Africa.
}

Accepted 25 April, 2008

\begin{abstract}
The glycoside, hypoxoside, identified and isolated from the corms of the African potato (Hypoxis hemerocallidea) has shown promising anticancer activities. The African potato is used as an African traditional medicine for its nutritional and medicinal properties. Most research has been carried out on $\boldsymbol{H}$. hemerocallidea (formerly known as $\boldsymbol{H}$. rooperi), with very little or nothing on other Hypoxis spp. Thin layer chromatography (TLC) was used to confirm the presence of sterols/sterolins, whereas a GC method was developed to identify and quantify sterols (especially $\beta$-sitosterol) in chloroform extracts of $H$. hemerocallidea, $H$. stellipilis and $H$. sobolifera var. sobolifera. High performance liquid chromatography (HPLC) was used to identify and quantify hypoxoside content in these Hypoxis spp. TLC results showed that $H$. sobolifera var. sobolifera contained the most sterols and sterolins compared to the other two Hypoxis spp. Gas chromatography (GC) results show that $\beta$-sitosterol and campesterol were the two main phytosterols present in the Hypoxis extracts. $H$. sobolifera var. sobolifera and $\boldsymbol{H}$. hemerocallidea contained the most $\beta$-sitosterol and hypoxoside, respectively. $H$. sobolifera and $H$. hemerocallidea contained $74.69 \mu \mathrm{g}$ of $\beta$-sitosterol and $12.27 \mu \mathrm{g}$ of hypoxoside per 5 $\mathrm{mg}$ of chloroform extracts, respectively. These results show a significant difference in the sterol/sterolin and hypoxoside contents between species of the genus Hypoxis, which may influence their degree of biological activities.
\end{abstract}

Key words: Hypoxis, TLC, GC, HPLC, sterol(in)s, hypoxoside.

\section{INTRODUCTION}

Hypoxis hemerocallidea Fisch., C.A. Mey. and Avé-Lall., syn. H. rooperi, (commonly known as the African potato; belonging to the family Hypoxidaceae) topped the list of the 60 most frequently traded plant species in the Eastern Cape, South Africa, when studies were conducted among street traders, traditional healers, storeowners and clinic patients (Dold and Cocks, 2002).

Glycosides, isolated from Hypoxis species, have a common pent-1-en-4-yne backbone or a slight modification of it (Sibanda et al., 1990; Messana et al., 1989; Marini-Bettolo et al., 1985; Nicoletti et al., 1992 and
*Corresponding author. E-mail: maryna.vandeventer@nmmu.ac.za. Tel: +27415042813. Fax: +27415042814 .

Marini-Bettolo et al., 1991). The glycoside, hypoxoside ((E)-1, 5-bis (4'- $\beta$-D-glucopyranosyloxy-3'-hydroxyphenyl) pent-4-en-1-yne) (Marini-Bettolo et al., 1982 and Drewes et al., 1984) has shown promising anticancer activities. In vitro conversion, catalyzed by $\beta$-glucosidase, of non-toxic hypoxoside to cytotoxic rooperol (Drewes and Liebenberg, 1987) has shown growth inhibition of 60 human cancer cell lines tested including breast, colon, uterus, melanoma and non-small cell lung cancer cell lines (Albrecht et al., 1995 and Smit et al., 1995).

Sterols are amphiphilic molecules consisting of hydroxyl groups forming the hydrophilic heads and sterane skeletons with side chains forming the hydrophobic tails 
(Heldt, 2005). Cholesterol $\left(\mathrm{C}_{27} \mathrm{H}_{45} \mathrm{OH}\right)$ is the main sterol found in mammals where it plays an important role in the structure and function of cell membranes, production of bile, as precursor of hormones and a role in the immune

system (De Brabander et al., 2007). Sterols found in plants are known as phytosterols and over 250 phytosterols and their related compounds have been identified (De Brabander et al., 2007) in foods like plant oils, nuts, seeds, cereals, fruits and vegetables (Piironen et al., 2000; Ostlund, 2002). Phytosterols differ from cholesterol in being alkylated at C-24 with $\mathrm{C}_{1}$ or $\mathrm{C}_{2}$ substituents (Buchanan et al., 2000). In nature, plants contain sterols with their associated sterolins (glucosides), which are easily destroyed by glycosidic enzymes (Pegel, 1976).

Phytosterols cannot be synthesized by humans and are thus consumed from the diet. The most commonly found phytosterols are sitosterol $\left(\mathrm{C}_{29}\right)$, campesterol $\left(\mathrm{C}_{28}\right)$ and stigmasterol $\left(\mathrm{C}_{29}\right)$ (Pegel, 1980; Ostlund, 2002). Phytosterols are incorporated in a variety of food products (functional foods (Vorster et al., 2003)) due to their cholesterol-lowering effect, hence providing protection against cardiovascular disease (Tapiero et al., 2003). Studies with phytosterols, especially $\beta$-sitosterol, have shown inhibition of several cancer cell lines including colon (Raicht et al., 1980; Choi et al., 2003 and Awad et al., 1998), prostate (von Holtz et al., 1998) and breast (Steenkamp and Gouws, 2006; Ju et al., 2004; Awad et al., 2003 and Awad et al., 2001). The role of plant sterols as immune modulators (Bouic et al., 2001; Bouic and Lamprecht, 1999; Bouic 2002 and Breytenbach et al., 2001) and anti-inflammatory agents (Quilez et al., 2003; Pegel, 1979) has also been described.

Some of the compounds (hypoxoside, $\beta$-sitosterol and other sterols/sterolins) that may be responsible for the medicinal properties of Hypoxis have been identified in $\mathrm{H}$. hemerocallidea but the quantity of these in different Hypoxis spp. is unknown. Various species of Hypoxis are sold and used indiscriminately without any evidence that they contain equal quantities of sterols/sterolins and hypoxoside. The main aims of this study were to identify and quantify the sterol/sterolin and hypoxoside contents of $H$. hemerocallidea, $H$. stellipilis Ker Gawl. and $H$. sobolifera var sobolifera (Jacq.) Nel.

\section{MATERIALS AND METHODS}

\section{Reagents and chemicals}

Sterol standards ( $\beta$-sitosterols [purity $>90 \%$ ], campesterol [purity $>$ $65 \%$ ], cholesterol [purity $>99 \%$ ], desmosterol [purity $\geq 85 \%$ ], ergosterol [purity $\geq 95 \%$ ], fucosterol [purity 95\%], stigmasterol [purity 95\%] and stigmastenol [purity > 95\%]) were purchased from Sigma Chemical Co. (MO, USA). HPLC grade acetonitrile and methanol were purchased from Romil Ltd. (Cambridge, UK). Water was obtained from a Milli-Q Compact System (Millipore, Bedford, MA).

\section{Plant material}

Corms of $H$. hemerocallidea (PEU 14798) and $H$. stellipilis (PEU 14841) were purchased in Port St Johns and Port Elizabeth (Xhosa traditional medicine shop), respectively, in the Eastern Cape, South Africa. Corms of $H$. sobolifera var sobolifera (PEU 14840) were

Boukes et al. $\quad 1625$

collected near Plettenberg Bay in the Southern Cape, South Africa. Corms of the three Hypoxis spp. were planted in the same soil type and exposed to equal amounts of sunlight, humidity and water for at least six months before they were harvested and used fresh. The plants were identified by $Y$. Singh from the South African National Biodiversity Institute (SANBI) and voucher specimens were deposited in the Nelson Mandela Metropolitan University herbarium.

\section{Isolation of hypoxoside and sterols/sterolins}

Corms of $H$. hemerocallidea, $H$. stellipilis and $H$. sabolifera were washed, peeled, grated and crushed using a mortar and pestle. Chloroform was added to the plant material in a 1:1 (v:w) ratio, vortexed ( $5 \mathrm{~min}$ ), extracted (15 min) and centrifuged ( $3645 \mathrm{xg}$ for 5 min) at room temperature. The supernatant was removed and the extracting method repeated with the same plant material. The chloroform was evaporated in vacuo and mass of extracts determined. After mass determination the extracts were redissolved in chloroform until further use.

\section{TLC}

$\beta$-Sitosterol $(2 \mu \mathrm{g})$ and stigmasterol $(2 \mu \mathrm{g})$ standards (Supelco, USA) and Hypoxis extracts $(500 \mu \mathrm{g})$ dissolved in chloroform were spotted onto $20 \times 20 \mathrm{~cm}$ silica coated aluminum plates (Merck, Germany) and air dried. Chromatogram tanks were equilibrated for one hour using toluene - diethyl ether $(40: 40, \mathrm{v} / \mathrm{v})$ and chloroform ethyl acetate - formic acid $(5: 4: 1, \mathrm{v} / \mathrm{v} / \mathrm{v})$ as mobile phases for sterol and sterolin identification, respectively. TLC plates were developed for $\pm 20 \mathrm{~min}$ or until the solvent front was $\pm 1 \mathrm{~cm}$ from the top of the plate. Detection of sterols/sterolins was performed as described by Scott and Springfield (2004). In brief, TLC plates were dried at room temperature and developed by firstly dipping into a solution containing $5 \%$ sulfuric acid in $96 \%$ ethanol for 15 s followed by a solution containing $1 \%$ vanillin in $96 \%$ ethanol for $15 \mathrm{~s}$ and dried at room temperature. Once dried, plates were heated at $80-100^{\circ} \mathrm{C}$ for five min. Photos of the developed TLC plates were taken with the Alphalmager ${ }^{\mathrm{TM}} 3400$ (Alpha Innotech.).

\section{GC}

GC analysis of sterols was performed using a Thermo Finnigan Focus gas chromatograph equipped with a FID and an Autoinjector AI3000, with Delta Chromatography 5.0 software. The column used for $\mathrm{GC}$ separation was a $\mathrm{SAC}^{\mathrm{TM}}-5$ capillary column (Supelco, $30 \mathrm{~m}$ $\times 0.25 \mathrm{~mm}$ i.d. $\times 0.25 \mu \mathrm{m}$ film thickness). The thermal conditions were: $80^{\circ} \mathrm{C}$ for $2 \mathrm{~min} ; 10^{\circ} \mathrm{C} \cdot \mathrm{min}^{-1}$ to $300^{\circ} \mathrm{C}$; $300^{\circ} \mathrm{C}$ for $14 \mathrm{~min}$. The carrier gas was $\mathrm{He}\left(1 \mathrm{ml} \cdot \mathrm{min}^{-1}\right.$ constant flow $)$ and the injection volume was $2 \mu \mathrm{l}$ (splitless). A sterol mixture (containing $100 \mu \mathrm{g} / \mathrm{ml}$ of each sterol standard) was spiked individually to identify the peaks. An increase in peak area was used as criteria to identify each peak.

\section{HPLC}

High performance liquid chromatography (HPLC) analysis of hypoxoside was performed using a Beckman System Gold high performance liquid chromatograph equipped with Solvent Module 
128, Diode Array Detector Module 169. The column used for HPLC separation was a Nucleosil $\mathrm{C}_{18}$ column (Supelco, $5 \mu \mathrm{m}, 150 \times 4.6$ $\mathrm{mm}$ i.d.). Detection of hypoxoside was performed as described by Nair and Kanfer (2006). In brief, acetonitrile - water (20:80, v/v) was used as mobile phase in isocratic mode at a flow rate of $1 \mathrm{ml} / \mathrm{min}$ and the injection volume was $10 \mu$ l. Detection was achieved in the 1626

$$
\text { Afr. J. Biotechnol. }
$$

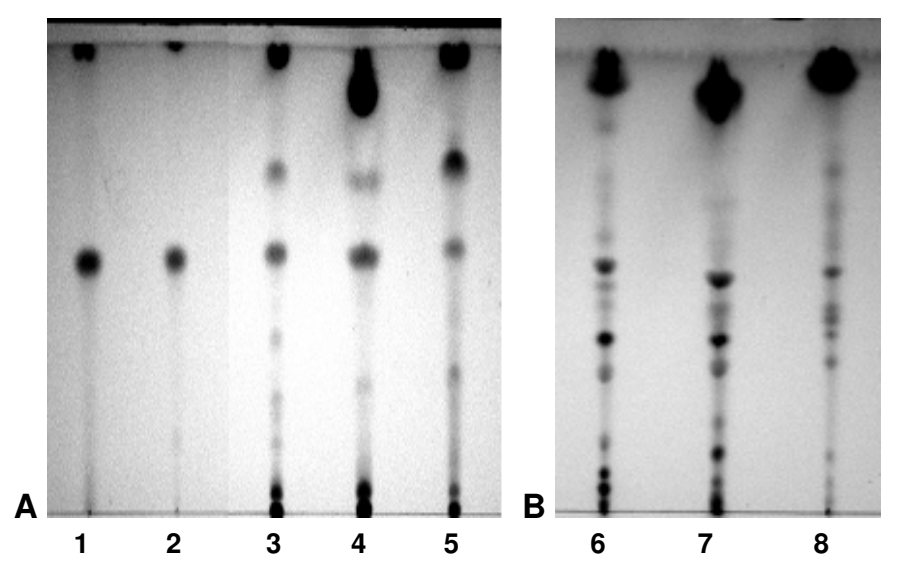

Figure 1. TLC plate of the (A) sterols and $(B)$ sterolins found in chloroform Hypoxis spp. extracts (1) $\beta$-sitosterol, (2) stigmasterol, (3/6) H. hemerocallidea, (4/7) H. sobolifera and (5/8) H. stellipilis.

range of 200 - $400 \mathrm{~nm}$ and hypoxoside was detected at a wavelength of $260 \mathrm{~nm}$. Stock solutions of hypoxoside $(1 \mathrm{mg} / \mathrm{ml}), H$. hemerocallidea $(5 \mathrm{mg} / \mathrm{ml}), H$. stellipilis $(10 \mathrm{mg} / \mathrm{ml})$ and $H$. sobolifera $(10 \mathrm{mg} / \mathrm{ml})$ were prepared in methanol and filtered through $0.2 \mu \mathrm{m}$ syringe filters (Corning Incorporated, New York, USA).

\section{RESULTS AND DISCUSSION}

Chloroform has been shown to be very effective in dissolving sterols (Toivo et al., 2000) due to its non-polar nature. The presence of sterols and sterolins in the chloroform extracts of $H$. hemerocallidea, $H$. stellipilis and $H$. sobolifera var sobolifera was confirmed via TLC. Modification of the mobile phase, toluene - diethyl ether - $1.75 \mathrm{M}$ acetic acid $(1: 1: 1, \mathrm{v} / \mathrm{v} / \mathrm{v})$ used by Scott and Springfield (2004), to toluene - diethyl ether (40:40, v/v) resulted in better sterol separation (Figure 1A). The spots of the sterol standards (stigmasterol and $\beta$-sitosterol) had the same $\mathrm{Rf}$ value of 0.53 . Cholesterol, campesterol, desmosterol, ergosterol, fucosterol and stigmastenol migrated the same distance on the TLC plates (data not shown), with the spots differing only in colour ranging from pink to blue. This made it impossible to identify and quantify individual sterols in the Hypoxis extracts, using TLC.

The mobile phase used for sterolin identification consisted of chloroform - ethyl acetate - formic acid $(5: 4: 1, \mathrm{v} / \mathrm{v} / \mathrm{v})$. The sterolins in the Hypoxis extracts could not be identified or quantified due to the unavailability of sterolin standards (Figure 1B). From the results obtained, different sterolins (based on $\mathrm{Rf}$ values) were detected and differences in sterolin composition could clearly be seen between the three Hypoxis species (Figure 1).
$\mathrm{GC}$ is the technique of choice to analyze the presence of sterols in food (Cunha et al., 2006; Contarini et al., 2002; Toivo et al., 2000; Lagarda et al., 2006 and Goudjil et al., 2003) due to shorter analysis times, less peak interference, improved resolution, greater detection sen-

sensitivity (low nanogram range) and thermal stability of the capillary columns (Abidi, 2001). The SAC-5 ${ }^{\text {TM }}$ capillary column, consisting of $95 \%$ dimethylpolysiloxane and $5 \%$ phenyl, is specially packed for the analysis of plant and animal sterols. The sterol/stanol standard mixture $(100 \mu \mathrm{g}$ of each sterol $/ \mathrm{mL})$, consisting of $\beta$-sitosterol (30.6 min), campesterol (29.3 $\mathrm{min}$ ), cholesterol (27.8 $\mathrm{min}$ ), desmosterol/ergosterol (28.9 $\mathrm{min})$, fucosterol (28.3 $\mathrm{min})$, stigmasterol (29.7 $\mathrm{min}$ ) and stigmastenol (30.9 $\mathrm{min})$ was well separated, except for desmosterol and ergosterol, which eluted at the same retention time, with good resolution on the SAC- $5^{\mathrm{TM}}$ column within a period of 32 min (Figure 2).

From GC analysis, it was clear that $\beta$-sitosterol was the main phytosterol found in the chloroform extracts of $H$. hemerocallidea, $H$. stellipilis and $H$. sobolifera. Trace amounts $(<10 \mu \mathrm{g}$ per $5 \mathrm{mg}$ of Hypoxis extract) of campesterol were also found in all three Hypoxis spp. extracts, whereas trace amounts of desmosterol/ ergosterol, stigmasterol, stigmastenol were found only in certain Hypoxis spp. A standard curve of $\beta$-sitosterol concentration (ranging between $10-100 \mu \mathrm{g} / \mathrm{mL}$ ) as a function of peak height $\left(R^{2}=0.9531, R_{T}=30.6 \mathrm{~min}\right)$ was used to quantify $\beta$-sitosterol content. $H$. sobolifera contained the most $\beta$-sitosterol with \pm 2.5 and 7.5 times more $\beta$-sitosterol compared to $H$. hemerocallidea and $H$. stellipilis, respectively (Table 1).

The presence of $\beta$-sitosterol and campesterol as the two major phytosterols in Hypoxis correspond to published data (Moghadasian, 2000; Pegel, 1976). According to a minireview by Moghadasian (2000), 95\% of dietary phytosterols consist of sitosterol and campesterol (approximately 65 and $30 \%$, respectively), whereas the other phytosterols (mainly stigmasterol) and stanols make up the other $5 \%$.

This is the first time that GC was used to identify and quantify the presence of sterols in Hypoxis extracts. Nair et al. (2006) have used high performance liquid chromatography to determine the presence of $\beta$-sitosterol, stigmasterol and stigmastenol in commercially available oral dosage forms reported to contain material or extracts of Hypoxis. Using the SAC- $5^{\mathrm{TM}}$ capillary column eliminated time-consuming preparation steps, for example extraction of lipid fraction from sample material, saponification (alkaline hydrolysis), extraction of nonsaponifiables and derivatization of the sterol standards and Hypoxis extracts (Toivo et al., 2000).

The presence of hypoxoside has been identified in several South African species of Hypoxis (Nicoletti et al., 1992) including $H$. hemerocallidea (Nair and Kanfer, 2006), but not in $H$. stellipilis or $H$. sobolifera. The HPLC method described by Nair and Kanfer (2006) was used to quantify hypoxoside content in the three Hypoxis spp (Figure 
3). Hypoxoside was detected after 12.5 minutes and quantified from a standard curve of hypoxoside concentra- tion (ranging between $5-100 \mu \mathrm{g} / \mathrm{mL}$ ) as a function of peak area $\left(\mathrm{R}^{2}=0.9971, \mathrm{R}_{\mathrm{T}}=30.6\right)$.

Of the three Hypoxis species tested for hypoxoside Boukes et al.
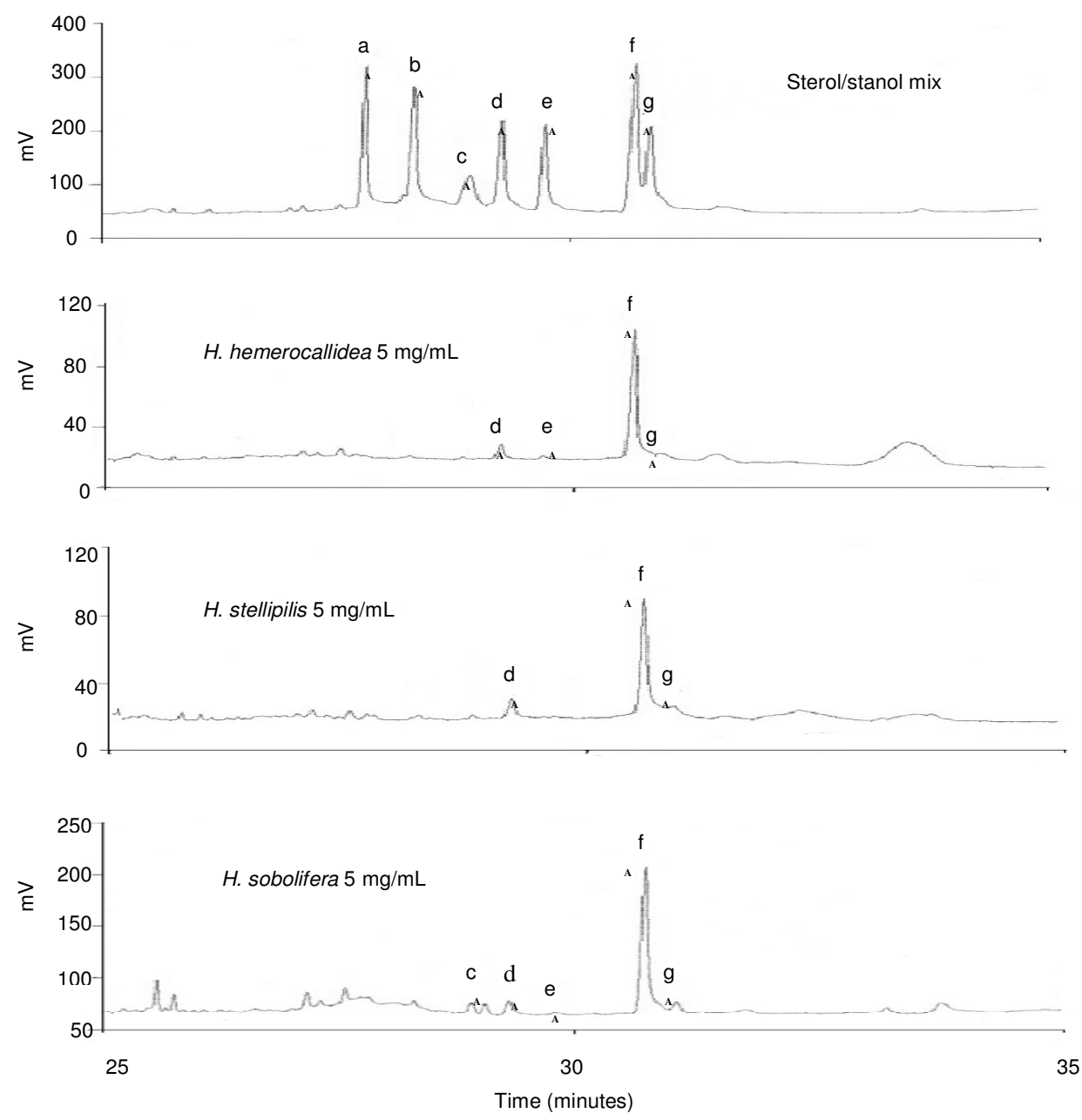

Figure 2. GC chromatograms of standards and chloroform Hypoxis extracts: (a) cholesterol, (b) fucosterol, (c) desmosterol/ergosterol, (d) campsterol, (e) stigmasterol, (f) $\beta$-sitosterol and (g) stigmastenol.

Table 1. Content and total percentage of $\beta$-sitosterol per $5 \mathrm{mg}$ of chloroform Hypoxis extracts.

\begin{tabular}{|l|c|c|}
\hline Hypoxis spp. & Content $(\boldsymbol{\mu g})$ & ${\text { Yield }(\%)^{\star}}^{*}$ \\
\hline H. hemerocallidea & 29.38 & 0.59 \\
H. stellipilis & 10.05 & 0.2 \\
H. sobolifera & 74.69 & 1.49 \\
\hline
\end{tabular}

${ }^{*} \mathrm{w} / \mathrm{w}$

content, only $H$. hemerocallidea and $H$. stellipilis contained hypoxoside. $H$. sobolifera, which showed the highest anticancer activity (unpublished data), had undetectable levels of hypoxoside (Table 2).

Since chloroform, the solvent used in this study, is not the best solvent for hypoxoside extraction, the presence of this glycoside in $H$. sobolifera was investigated using more polar solvents. A water extract of $H$. sobolifera has shown no hypoxoside content, whereas ethanol, methaTable 2. Content and total percentage of hypoxoside per $5 \mathrm{mg}$ of chloroform Hypoxis extracts

\begin{tabular}{|l|c|c|}
\hline \multicolumn{1}{|c|}{ Hypoxis spp. } & Content $(\boldsymbol{\mu g})$ & ${\text { Yield }(\%)^{*}}^{*}$ \\
\hline H. hemerocallidea & 12.27 & 0.12 \\
H.stellipilis & 7.93 & 0.08 \\
H. sobolifera & Undetectable & - \\
\hline
\end{tabular}

${ }^{*} \mathrm{w} / \mathrm{w}$

nol and acetone extracts of $H$. sobolifera yielded 60.66, 49.13 and $60.35 \mu \mathrm{g}$ per $5 \mathrm{mg}$ of extract, respectively. Hypoxoside is therefore present in $H$. sobolifera but in much smaller amounts than in $H$. hemerocallidea and $H$. stellipilis. Previous studies have used $30-75 \%$ ethanol 
(Pegel, 1979) and methanol (Nair and Kanfer, 2006) to extract hypoxoside from $H$. hemerocallidea. Traditional 1628
Afr. J. Biotechnol. healers/herbalists use water and boiling to make Hypoxis extracts, which may yield hypoxoside and sterolins
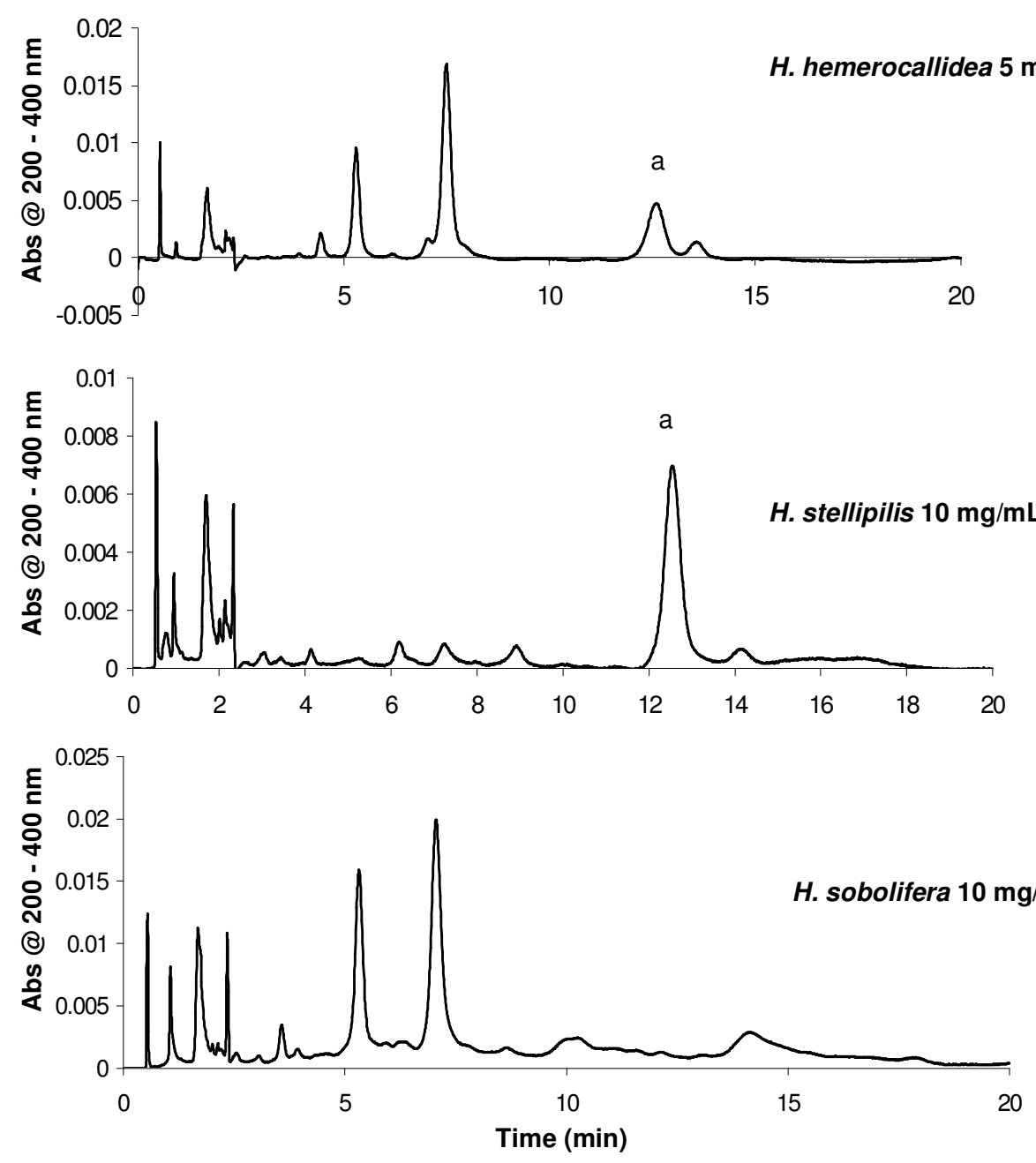

Figure 3. HPLC chromatograms of the hypoxoside content of chloroform Hypoxis extracts: (a) hypoxoside detected at $260 \mathrm{~nm}$.

(Pegel, 1976). Due to the polar nature of hypoxoside it would be better to use more polar solvents for extractions in the future, if more emphasis is placed on the effect of hypoxoside in the Hypoxis extracts.

This is the first time that hypoxoside and sterol contents were quantified in $H$. stellipilis and $H$. sobolifera, and as far as we know in $H$. hemerocallidea. Both the sterol and hypoxoside contents were shown to vary between the three species. Differences in the hypoxoside and sterol/sterolin contents of the three Hypoxis spp. investigated may explain the differences in anticancer activity (unpublished data) obtained against certain cancer cell lines. Hypoxis species are used indiscriminately in traditional medicine and are sold under the common name 'African potato' in herbal shops. Further investigation is required to determine the implications of these findings in the uses of Hypoxis as a traditional remedy. Consumption of the three different Hypoxis species, which have different sterols/sterolins and hypoxoside content, may have adverse or favorable effects depending on the concentration of extract consumed. Sterols/sterolins and hypoxoside may have synergistic effects, which need to be investigated.

\section{ACKNOWLEDGMENTS}

The authors want to thank the NRF (GUN 2069228) and the MRC for funding this study, and Dr. C. Albrecht for donating purified hypoxoside.

\section{REFERENCES}

Abidi SL (2001). Chromatographic analysis of plant sterols in foods and vegetable oils. J. Chromatogr. A 935: 173-201. 
Albrecht CF, Theron EJ, Kruger PB (1995). Morphological characterization of the cell-growth inhibitory activity of rooperol and pharmacokinetic aspects of hypoxoside as an oral prodrug for cancer therapy. S. Afr. Med. J. 85: 853-860.

Awad AB, Fink CS (2000). Phytosterols as anticancer dietary components: evidence and mechanism of action. J. Nutr. 130: 2127-2130.
Marini-Bettolo GB, Patamia M, Nicoletti M, Galeffi C, Messana I (1982). Hypoxoside, a new glycoside of uncommon structure from Hypoxis obtusa Busch. Tetrahedron 38: 1683-1687.

Messana I, Msonthi JD, De Vicente Y, Multari G, Galeffi C (1989). Mononyasine $A$ and mononyasine $B$ : two glucosides from Hypoxis nyasica. Phytochemistry 29: 2807-2809.

Boukes et al.
Awad AB, von Holtz RL, Cone JP, Fink CS, Chen YC (1998). Bsitosterol inhibits the growth of HT-29 human colon cancer cells by activating the sphingomyelin cycle. Anticancer Res. 18: 471-479.

Awad AB, Williams H, Fink CS (2001). Phytosterols reduce in vitro metastatic ability of MDA-MB-231 human breast cancer cells. Nutr. Cancer 40: 157-164.

Awad AB, Williams $\mathrm{H}$, Fink CS (2003). Effect of phytosterols on cholesterol metabolism and MAP kinase in MDA-MB-231 human breast cancer cells. J. Nutr. Biochem. 14: 111-119.

Bouic PJD (2002). Sterols and sterolins: new drug for the immune system? DDT 7: 775-778.

Bouic PJD, Etsebeth S, Liebenberg RW, Albrecht CF, Pegel K, van Jaarsveld PP (1996). Beta-sitosterol and beta-sitosterol glucoside stimulate human peripheral blood lymphocyte proliferation: implications for their use as an immunomodulatory vitamin combination. Int. J. Immunopharmacol. 18: 693-700.

Bouic PJD, Lamprecht JH (1999). Plant sterols and sterolins: a review of their immune-modulating properties. Altern. Med. Rev. 4: 170-177.

Breytenbach U, Clark A, Lamprecht J, Bouic PJD (2001). Flow cytometry analysis of the Th1-Th2 balance in healthy individuals and patients infected with the human immunodeficiency virus (HIV) receiving a plant sterol/sterolin mixture. Cell Biol. Int. 25: 43-49.

Buchanan BB, Gruissem W, Jones RL (2000). Biochemistry and molecular biology of plants. American Society of Plant Physiologists, Rochville (Maryland), pp 901-911.

Choi YH, Kong KR, Kim YA, Jung KO, Kil JH, Rhee SH, Park KY (2003). Induction of $\mathrm{Bax}$ and activation of caspases during $\beta$ sitosterol-mediated apoptosis in human colon cancer cells. Int. J. Oncol. 23: 1657-1662.

Contarini G, Povolo M, Bofitto E, Berardi S (2002). Quantitative analysis of sterols in dairy products: experiences and remarks. Int. Dairy J. 12: 573-578.

Cunha SS, Fernandes JO, Oliveira MBPP (2006). Quantification of free and esterified sterols in Portuguese olive oils by solid-phase extraction and gas chromatography-mass spectrometry. J. Chromatogr. A 1128: 220-227.

De Brabander HF, Verheyden K, Mortier V, Le Bizec B, Verbeke V, Courtheyn D, Noppe H (2007). Phytosterols and anabolic agents versus designer drugs. Anal. Chim. Acta 586: 49-56.

Dold AP, Cocks ML (2002). The trade in medicinal plants in the Eastern Cape Province, South Africa. S. Afr. J. Sci. 98: 589-597.

Drewes SE, Hall AJ, Learmonth RA, Upfold UJ (1984). Isolation of hypoxoside from Hypoxis rooperi and synthesis of (E)-1,5-bis(3',4'dimethoxyphenyl)pent-4-en-1-yne. Phytochemistry 23: 1313-1316.

Drewes S, Liebenberg RW (1987). Rooperol and its derivates. U.S. Patent 4644085.

Goudjil H, Torrado S, Fontecha J, Martínez-Castro I, Fraga MJ, Juárez M (2003). Composition of cholesterol and its precursors in ovine milk. Lait 83: 153-160.

Heldt HW (2005). Plant Biochemistry $3^{\text {rd }}$ Ed., Elsevier Academic Press, London, pp 364-367.

Ju YH, Clausen LM, Allred KF, Almada AL, Helferich WG (2004). $\beta$ sitosterol, $\beta$-sitosterol glucoside, and a mixture of $\beta$-sitosterol and $\beta$ sitosterol glucoside modulate the growth of estrogen-responsive breast cancer cells in vitro and in ovariectomized athymic mice. J. Nutr. 134: 1145-1151.

Lagarda MJ, García-Llata G, Farré R (2006). Analysis of phytosterols in food. J. Pharm. Biomed. Anal. 40: 1486-1496.

Marini-Bettolo GB, Galeffi C, Multari G, Palazzino G, Messana I (1991). Interjectin, a derivative of nyasicoside from Hypoxis interjecta and Hypoxis multiceps. Tetrahedron 37: 6717-6724.

Marini-Bettolo GB, Nicoletti M, Messana I, Galeffi C, Msonthi JD, Chapya WA (1985). Glucosides of Hypoxis nyasica Bak. The structure of nyasoside, a new glucoside biologically related to hypoxoside. Tetrahedron 41: 665-670.
Moghadasian MH (2000). Pharmacological properties of plant sterols in vivo and in vitro observations. Life Sci. 67: 605-615.

Nair VDP, Kanfer I (2006). High-performance liquid chromatography method for the quantitative determination of hypoxoside in African potato (Hypoxis hemerocallidea) and commrcial products containing the plant material and/or its extracts, J. Agric. Food Chem. 54: 28162821.

Nair VDP, Kanfer I, Hoogmartens J (2006). Determination of stigmasterol, $\beta$-sitosterol and stigmastenol in oral dosage forms using high performance liquid chromatography with evaporative light scattering detection. J. Pharm. Biomed. Anal. 41: 731-737.

Nicoletti M, Galeffi C, Messana I, Marini-Bettolo GB (1992). Hypoxidaceae. Medicinal uses and the norlignan constituents. J. Ethnopharmacol. 36: 95-101.

Ostlund RE (2002). Phytosterols in human nutrition. Annu. Rev. Nutr. 22: $533-549$.

Pegel KH (1976). Extraction of sterolins from plant material. U.S. Patent 3933789.

Pegel KH (1979). Active plant extracts of Hypoxidaceae and their use. U.S. Patent 4160860.

Pegel KH (1980). Sterolins and their use. U.S. Patent 4188379

Piironen V, Lindsay DG, Miettinen TA, Toivo J, Lampi AM (2000). Plant sterols: biosynthesis, biological function and their importance to human nutrition. J. Sci. Food Agric. 80: 939-966.

Quilez J, Garcia-Lorda P, Salas-Salvado J (2003). Potential uses and benefits of phytosterols in diet: present situation and future directions. Clin. Nutr. 22: 343-351.

Raicht RFD, Cohen BI, Fazzini EP, Sarwal AN, Takahashi M (1980). Protective effect of plant sterols against chemically induced colon tumors in rats. Cancer Res. 40: 403-405.

Scott G, Springfield EP (2004). Pharmaceutical monographs of 60 indigenous plant species used as traditional medicines in South Africa. South African National Biodiversity Institute (SANBI) plant information website at www.plantzafrica.com.

Sibanda S, Ntabeni O, Nicoletti M, Galeffi C (1990). Nyasol and 1,3(5)diphenyl-1-pentene related glycosides from Hypoxis angustifolia. Biochem. Syst. Ecol. 18: 481-483.

Smit BJ, Albrecht CF, Liebenberg RW, Kruger PB, Freestone M, Gouws L, Theron E, Bouic PJD, Etsebeth S, van Jaarsveld PP (1995). A phase I trial of hypoxoside as an oral prodrug for cancer therapy absence of toxicity. S. Afr. Med. J. 85: 865-870.

Steenkamp V, Gouws MC (2006). Cytotoxicity of six South African medicinal plant extracts used in the treatment of cancer. SAJB 72 : 630-633.

Tapiero H, Townsend DM, Tew KD (2003). Phytosterols in the prevention of human pathologies. Biomed. Pharmacother. 57: 321 325.

Toivo J, Lampi A-M, Aalto S, Piironen V (2000). Factors affecting sample preparation in the gas chromatographic determination of plant sterols in whole wheat flour. Food Chem. 68: 239-245.

Vorster HH, Raal FJ, Ubbink JB, Marais AD, Rajput MC, Ntanois FY (2003). Functional foods with added plant sterols for treatment of hypercholesterolaemia and prevention of ischaemic heart disease. SAJCN 16: 49-58.

von Holtz RL, Fink CS, Awad AB (1998). $\beta$-sitosterol activates the sphingomyelin cycle and induces apoptosis in $\mathrm{LNCaP}$ human prostate cancer cells. Nutr. Cancer 32: 8-12. 